\title{
Pękanie spoin w procesie krzepnięcia
}

\section{Fracture of joints during solidification process}

\section{STRESZCZENIE}

Scharakteryzowano mechanizmy powstawania pęknięć krystalizacyjnych w spoinach oraz w strefie wpływu ciepła, różnych stopów i podano możliwe sposoby ich ograniczenia.

\section{Pęknięcia krystalizacyjne w spoinie}

Charakterystyczną cechą pęknięć krystalizacyjnych jest ich usytuowanie wewnątrz spoiny najczęściej w osi (rys. 1). W procesie spawania krystalizujący metal spoiny znajduje się pod wpływem naprężeń rozciągających. Naprężenia te powstają w wyniku nieswobodnego skurczu spoiny i stygnięcia nierównomiernie nagrzanego materiału spawanego. Pod wpływem tych naprężeń metal spoiny odkształca się, a przy niedostatecznej zdolności do odkształceń - pęka.
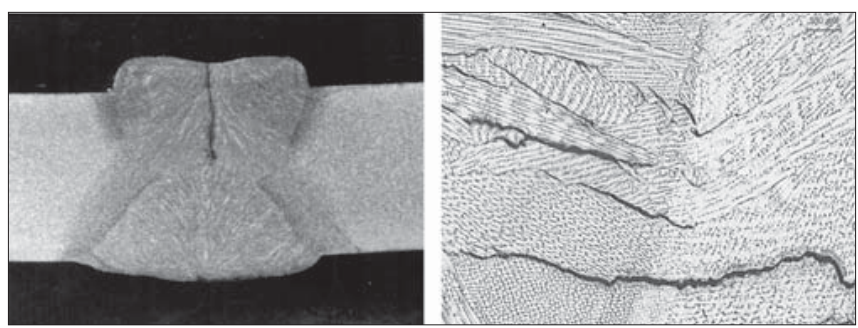

Rys. 1. Pęknięcie krystalizacyjne w spoinie: a) - stali niestopowej, b) stali austenitycznej

Pękanie spoin w procesie krzepnięcia uwarunkowane jest składem chemicznym metalu spoiny i zakresem temperatur krzepnięcia oraz warunkami i charakterem procesu krystalizacji. Ponadto istotny jest stopień rozwoju wewnątrzkrystalicznej niejednorodności, a także konstrukcją i sztywnością połączenia spawanego.

Proces pękania w czasie krzepnięcia przebiega w tzw. zakresie kruchości wysokotemperaturowej (ZKW), który jest ograniczony od góry tzw. temperaturą wytrzymałości zerowej (nil strength temperature, NST), to znaczy najniższą temperaturą, przy której materiał ulega zerwaniu przy zerowym poziomie naprężeń. Natomiast od dołu temperaturą powrotu ciągliwości (ductility recovery temperature, DRT), położenie tych temperatur ilustruje rysunek 2. Na rysunku tym zaznaczono również temperaturę ciągliwości zerowej (nil ductility temperature, NDT), czyli temperature, przy której podczas nagrzewania materiał pęka z przewężeniem równym zero.

W procesie krystalizacji po ochłodzeniu do temperatury NST ziarna zaczynają się ze sobą stykać tworząc „mostki” (rys. 3). Utrudniona zostaje wówczas swobodna cyrkulacja cieczy odpowiedzialna za plastyczność stopu. Poniżej temperatury NST metal spoiny ma już pewną wytrzymałość mechaniczną, jednak granice styków krystalitów nie są jeszcze zdolne do przenoszenia odkształceń plastycznych. Temperature, w której to występuje nazywamy górną granicą ZKW. Odkształcenia skurczowe mogą więc doprowadzić do

Prof. dr hab. Edmund Tasak, dr inż. Aneta Ziewiec - AGH, Karaków

\section{ABSTRACT}

Mechanisms of crystallizing fracture formation in the joints and in the heat-affected zones in the case of various of alloys were characterised, and feasible methods were given to keep them within limits.

powstawania mikropęknięć (mikroszczelin) po granicach krystalitów, na których proces krystalizacji jeszcze nie zakończył się. Powstałe pęknięcia (szczeliny) nie są usuwane w wyniku dopływu ciekłego metalu, przez tzw. "samozaleczenie", gdyż postępujący proces krystalizacji zamyka jego dopływ. W procesie dalszego chłodzenia krzepną warstwy międzydendrytyczne, a ich wytrzymałość osiąga poziom umożliwiający przejęcie przez kryształy odkształceń plastycznych. Od tego momentu odkształcenie metalu zachodzi na drodze transkrystalicznych poślizgów, a zerwana próbka ma już określone wydłużenie (przewężenie) większe od zera. Temperaturę, w której to zachodzi nazywa się temperaturą DRT lub dolną granicą ZKW.

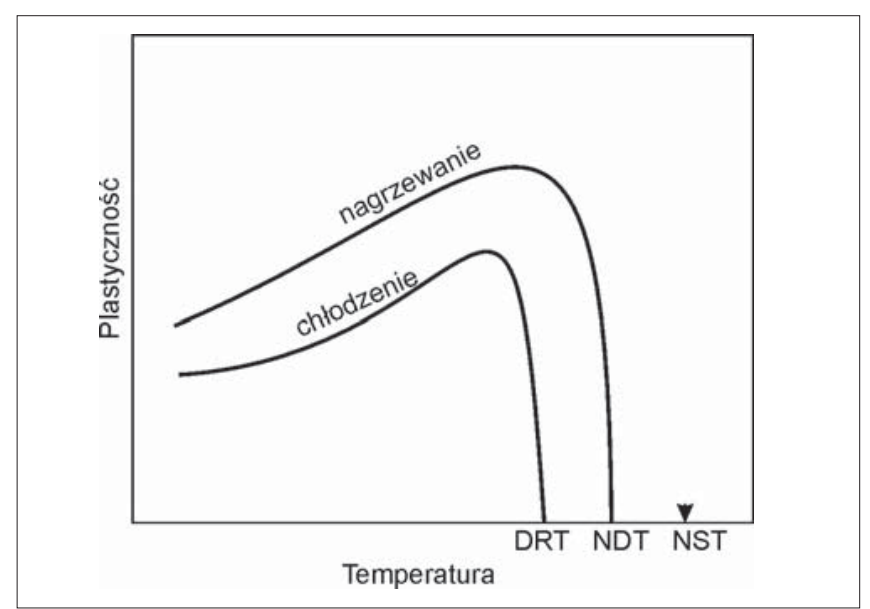

Rys. 2. Schemat zmian plastyczności stopu podczas nagrzewania i chłodzenia oraz Iokalizacja: temperatury ciągliwości zerowej (NDT), temperatury zerowej wytrzymatości (NST) i temperatury powrotu ciągliwości przy chłodzeniu (DRT)
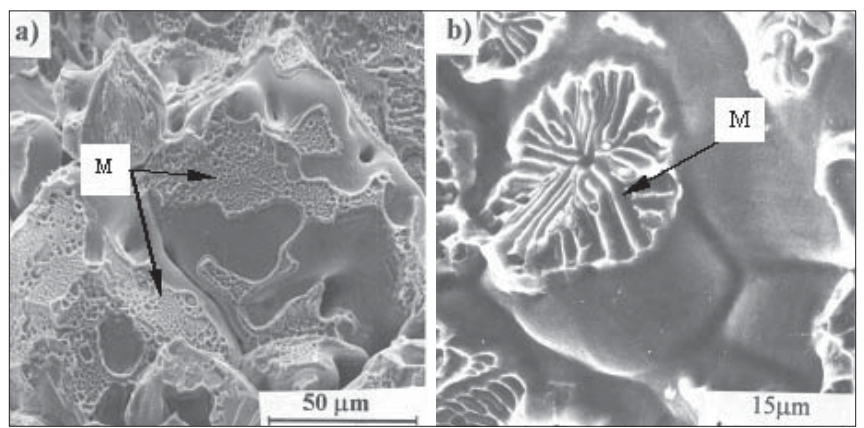

Rys. 3. Charakterystyczne miejsca styku dendrytów - „mostki” (M) na powierzchni pęknięcia gorącego w spoinie stali a) St3S, b) 18G2A. Istotnym czynnikiem wpływającym na skłonność do pękania krystalizacyjnego jest charakter struktury powstającej w czasie krzepnięcia. Wpływ charakteru krystalizacji na zapas plastyczności stopu, a tym samym skłonność do pęknięć krystalizacyjnych ilustruje rysunek 4 


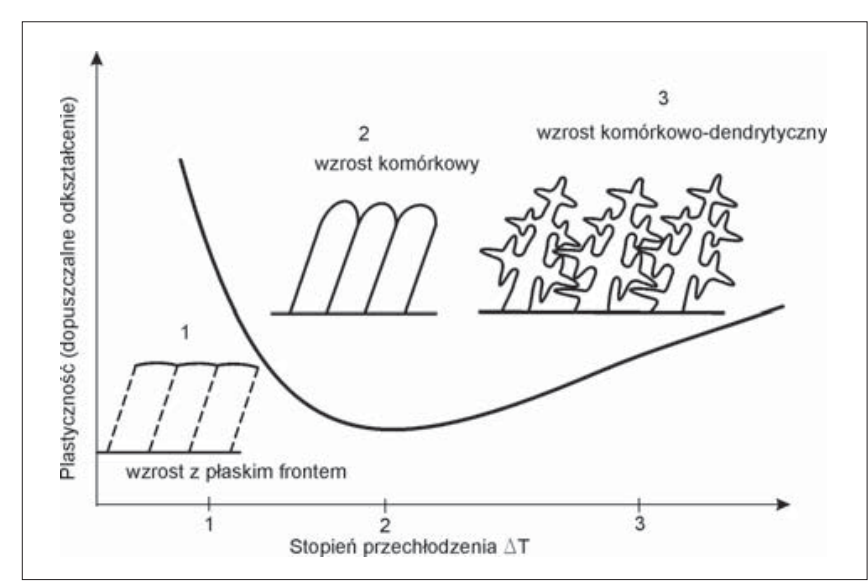

Rys. 4. Wpływ charakteru krystalizacji na plastyczność stopu (wielkość dopuszczalnych odkształceń)

Istotnym czynnikiem wpływającym na skłonność do pękania krystalizacyjnego jest charakter struktury powstającej w czasie krzepnięcia. Wpływ charakteru krystalizacji na zapas plastyczności stopu, a tym samym skłonność do pęknięć krystalizacyjnych ilustruje rysunek 4.

Z przedstawionego schematu wynika, że największą skłonność do pękania posiadają spoiny, w których w czasie krzepnięcia powstaje struktura komórkowa. Pękaniu tych spoin sprzyjają stosunkowo gładkie powierzchnie granic komórek, na których występuje silna segregacja niskotopliwych składników. Przy krzepnięciu komórkowodendrytycznym powierzchnia właściwa granic krystalitów jest większa, a zatem stężenie niskotopliwych faz na jednostkę powierzchni mniejsze i mniejsza skłonność do pękania. Ponadto podczas wzrostu, dendryty komórkowe wzajemnie „zazębiają” się bocznymi gałęziami, przez co spoina uzyskuje dodatkowy wzrost wytrzymałości i obniżenie skłonności do pękania. Przy płaskim froncie krzepnięcia występującym przeważnie w czystych metalach, nie ma segregacji a zatem odporność tych spoin na pękanie krystalizacyjne jest duża.

Austenityczne stale chromowo-niklowe mają w porównaniu ze stalami ferrytycznymi znacznie wyższy współczynnik rozszerzalności cieplnej a jednocześnie niższy współczynnik przewodnictwa cieplnego. Średni współczynnik rozszerzalności cieplnej dla stali ferrytycznych wynosi ok. $12 \cdot 10^{-6} 1 / \mathrm{K}$, natomiast stali austenitycznych $18 \cdot 10^{-6}$ 1/K. W związku z tym występują znaczne odkształcenia cienkościennych połączeń spawanych względnie duże naprężenia spawalnicze w połączeniach grubościennych, znacznie wyższe aniżeli w stalach niestopowych. W połączeniach grubościennych istnieje zatem niebezpieczeństwo wystąpienia pęknięć w czasie krzepnięcia spoiny (pęknięcia krystalizacyjne) jak i w czasie ponownego nagrzewania materiału podstawowego i spoiny (pęknięcia segregacyjne). Schemat uzyskiwania peknięć w złączu spawanym przedstawia rysunek 5.

Skłonność austenitycznych stali chromowo-niklowych do pękania na gorąco uzależniona jest $w$ dużym stopniu od jej składu chemicznego, a tym samym od sposobu i charakteru krzepnię-

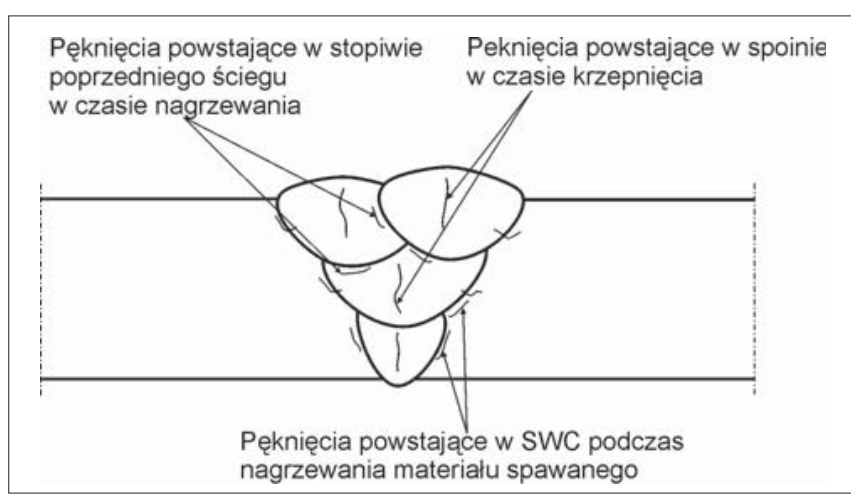

Rys. 5. Miejsca usytuowania pęknięć w złączach spawanych stali austenitycznych Cr-Ni cia oraz rodzaju pierwotnie krzepnącej fazy (austenit czy ferryt). W zależności od rodzaju krystalizującej pierwotnej fazy, segregujące domieszki mogą skutecznie zwiększać skłonność do pękania. Spoiny austenityczne krzepnące z pierwotnie wydzielonym austenitem są bardziej skłonne do pęknięć niż spoiny krzepnące pierwotnie jako ferrytyczne lub ferrtyczno-austenityczne. Jest to związane z tym, że zanieczyszczenia takie jak S, P, Si, Sn, Sb, itd. znacznie rozszerzające zakres temperatur krzepnięcia, mogą w czasie pierwotnej krystalizacji ferrytycznej z uwagi na większą rozpuszczalność w ferrycie łatwiej się w nim rozpuszczać i tym samym zmniejszać stężenie domieszki na granicach ziaren. Wśród składników stopowych i towarzyszących: nikiel, tantal, krzem, tytan i niob - zwiększają skłonność do pękania, natomiast chrom, wolfram, molibden, mangan i azot zmniejszają.

Składniki dodatkowe i zanieczyszczenia: cyrkon, bor, siarka i fosfor zwiększają skłonność do pękania. Szkodliwość i segregacja niektórych składników można wyjaśnić następująco:

Na skutek segregacji składników w końcowym etapie krzepnięcia powstaje ciekła błonka międzydendrytyczna o niskiej temperaturze topnienia, która pozbawia strukturę spójności, w momencie t.j. gdy zaczynają występować naprężenia spowodowane skurczem. W ten sposób można wyjaśnić wpływ fosforu, boru oraz siarki, które tworzą złożone eutektyki o niskiej temperaturze topnienia, szczególnie z niklem. Odnosi się to również do niobu, który tworzy złożone eutektyki z węglem, azotem, krzemem, żelazem oraz manganem. Niekorzystny wpływ krzemu na skłonność do pękania austenitu chromowo-niklowego można wyjaśnić następująco. W pierwszym okresie krzepnięcia metal spoiny zawierającej np. 18\% Cr i $8 \% \mathrm{Ni}$ krzepnie tworząc kryształy ferrytu $\delta$ bogatego w chrom oraz krzem. Tym samym pozostała ciecz ubożeje w te składniki a wzbogaca się w nikiel. W miare spadku temperatury tworzą się kryształy austenitu bogate w nikiel. Następnie kryształy ferrytu $\delta$ wzbogacone w krzem przemieniają się w austenit, który wykazuje dużą skłonność do tworzenia pęknięć. Stwierdzono również, że w temperaturze krzepnięcia krzem tworzy z żużlem niskotopliwe związki wydzielające się na granicach ziaren, obniżając tym samym wytrzymałość metalu w wysokich temperaturach.

\section{Sposoby ograniczenia skłonności do pękania krystalizacyjnego spoin}

Istotnym czynnikiem wpływającym na skłonność do pękania gorącego spoin jest stopień wymieszania. Na rysunku 6 pokazano

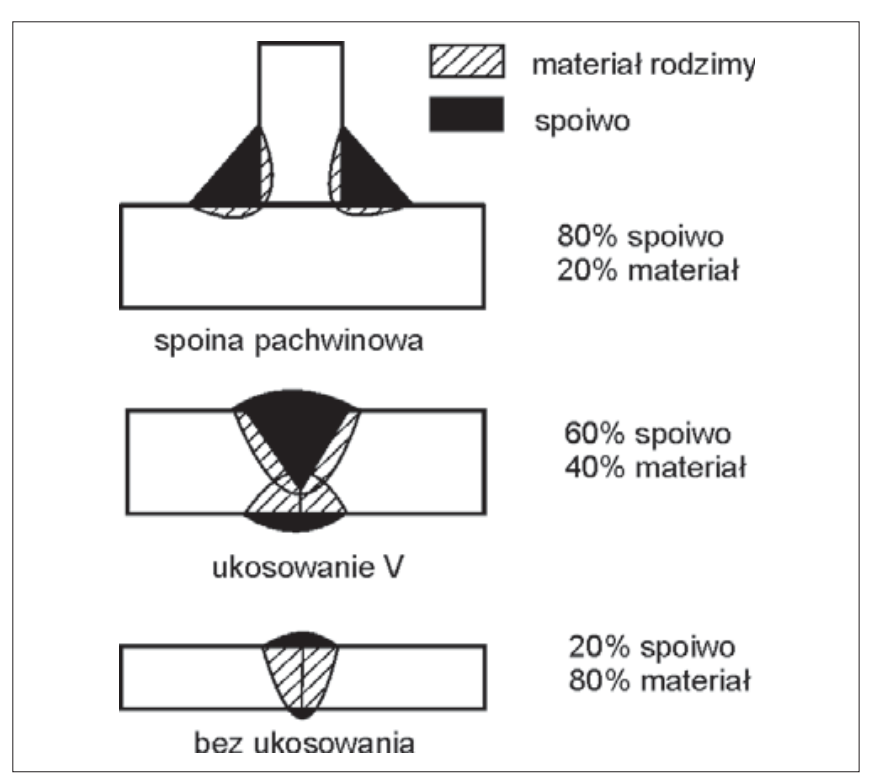

Rys. 6. Orientacyjne stopnie rozcieńczenia spoiwa przy przy różnym sposobie przygotowania krawędzi i rodzaju spawania. 


\section{Optymalizacja kształtu spoiny}

0 wielkości naprężeń spawalniczych decyduje również kształt ułożonego ściegu. Spoina krzepnąc kurczy się i ostatni ścieg w zależności od sposobu układania może być wklęsty lub wypukły. Na rysunku

Rys. 7. Wpływ stopnia wymieszania stopiwa na skłonność do pęknięć gorących (schemat) [1] jak rodzaj złącza i sposób ukosowania wpływa na rozcieńczenie spoiwa, a zatem na skłonność do pękania. Ma to szczególne znaczenie przy spawaniu stali austenitycznych spoiwami na bazie niklu. Na rysunku 7 przedstawiono przykład jak stopień wymieszania stopiwa przy spawaniu stali austenitycznej zawierającej 6\%Mo elektrodą EL-NiCr ${ }_{20} \mathrm{Mog}_{9} \mathrm{Nb}$ wpływa na skłonność spoin do pękania na gorąco. Z danych przedstawionych na rysunku widać, że podwyższenie zawartości niklu w stopiwie od 30 do $45 \%$ i stopień wymieszania ponad 35\% podwyższają skłonność do pękania.

Zgodnie z tym, przygotowanie brzegów elementów spawanych, jak też technologia spawania powinny być tak dobrane, aby nie przekroczyć maksymalnego wynoszącego 35\% stopnia wymieszania. Zawartość niklu w przedziale $30 \pm 45 \%$ oddziałuje bardzo niekorzystnie na odporność stopiwa na pęknięcia gorące. Sposobem zabezpieczenia w spoinie wystarczającej ilości czystego stopiwa na bazie niklu jest odpowiednie przygotowanie rowka do spawania z odstępem $2 \pm 3 \mathrm{~mm}$ i kątem ukosowania powyżej $70^{\circ}$.

Do oceny skłonności spoiny do pęknięć gorących krystalizacyjnych podczas spawania materiałów różnorodnych, można wykorzystać wykres Schaefflera (rys. 8).

Zakładając, że stale St3S i 1H18N9T w równym stopniu przechodzą do spoiny (w stosunku 1:1) łączymy ten punkt z punktem określającym skład elektrody. Jeśli w spoinie udział materiałów rodzimych będzie $20 \%$, punkt odpowiadający $20 \%$ udziałowi materiału rodzimego określa nam strukturę otrzymanej spoiny. W tym przypadku struktura spoiny będzie austenityczno-ferrytyczna z 16\% udziałem ferrytu, a zatem znajdzie się w obszarze wykresu, w którym struktury spoin nie wykazują skłonności do pęknięć gorących ani nie są kruche w wyniku wydzielania fazy $\sigma$.

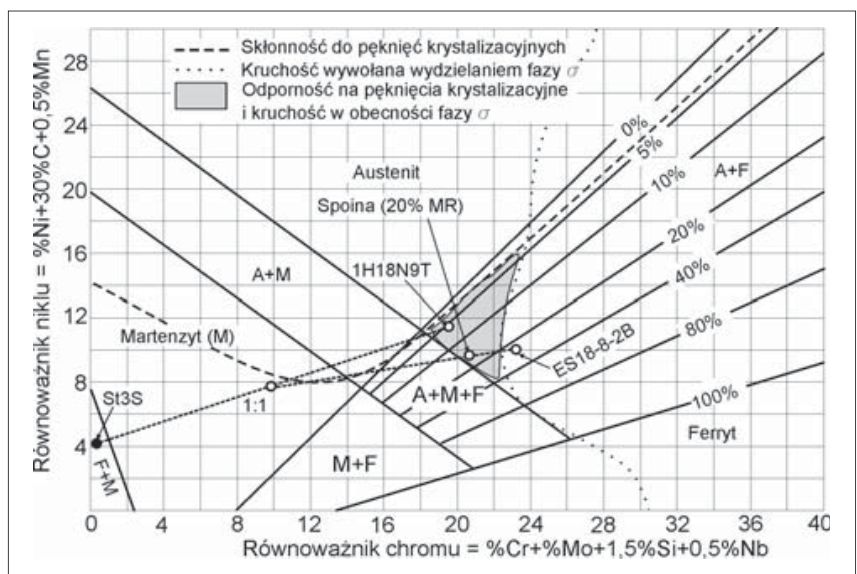

Rys. 8. Sposób określania składu i struktury spoiny

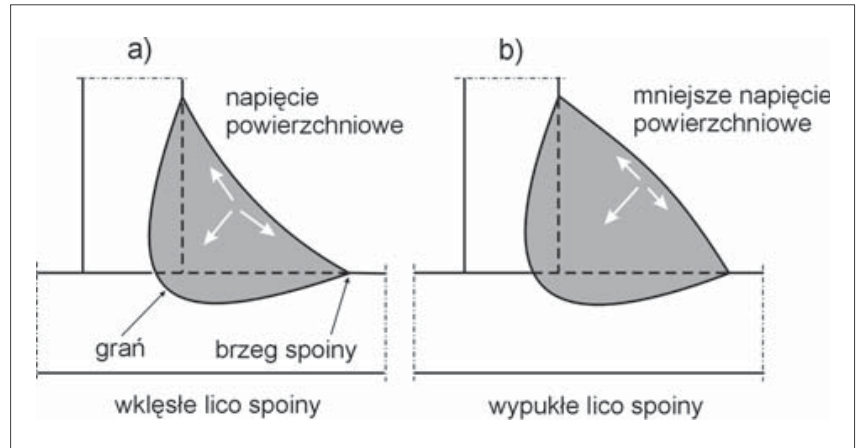

Rys. 9. Wpływ ksztattu jeziorka spawalniczego na stan naprężeń w środowej części powierzchni lica spoiny

pokazano że przy ściegu wypukłym naprężenia się rozkładają i redukują, a tendencja do zainicjowania pęknięcia na powierzchni zewnętrznej zmniejsza się. Jednakże wypukły ścieg może powodować powstanie podtopień, przez co obniża się wytrzymałość zmęczeniowa oraz odporność na pękanie wodorowe od brzegu spoiny. Przy spawaniu

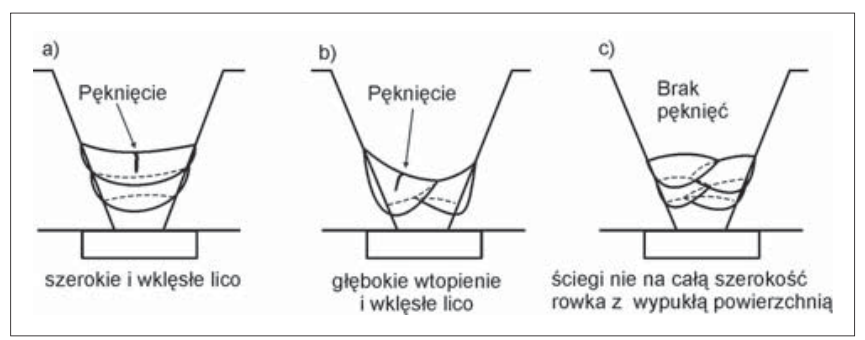

Rys. 10. Wpływ ksztattu jeziorka spawalniczego na pękanie krystalizacyjne przy spawaniu wielościegowym: a - ściegi wklęsłe, b - ściegi wklęsłe i głęboki przetop, c - małe wtopienie i ściegi lekko wypukłe

wielowarstwowym pęknięcie może być zainicjowane na powierzchni ostatniego ściegu, jeśli ściegi są zbyt szerokie i wklęsłe (rys. 10). Ściegi wypukłe obniżają skłonność do pękania krystalizacyjnego, zwiększają jednak możliwość powstania niezgodności spawalniczych w postaci zażużleń przy brzegu spoiny, spowodowanych trudnościami z dokładnym usunięciem żużla.

\section{Pęknięcia segregacyjne w SWC}

Występowanie pęknięć na gorąco w strefie wpływu ciepła stali niskowęglowych i stopowych obserwuje się przede wszystkim w strukturze obszaru leżącego w bezpośrednim sąsiedztwie spoiny, tj. w obszarze częściowego stopienia oraz w obszarze przegrzania (rys. 11, 12). Mają one charakter pęknięć międzykrystalicznych usytuowanych najczęściej prostopadle do kierunku działania naprężeń ciepInych. Pęknięcia segregacyjne mają z reguły przebieg dwustopniowy.

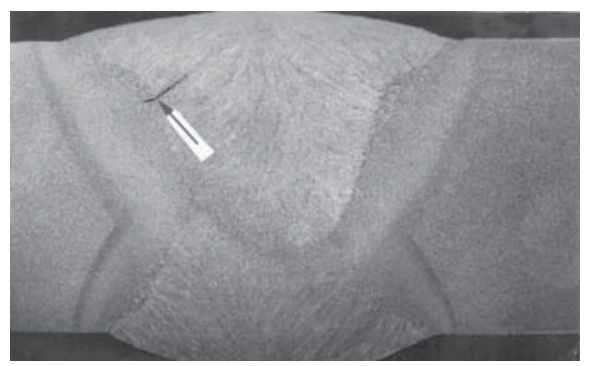

Rys. 11. Makrostruktura spoiny wykonanej fukiem krytym z widocznym pęknięciem segregacyjnym rozwijającym w pobliżu linii wtopienia ( $w$ strefie wpływu ciepła i w spoinie) 


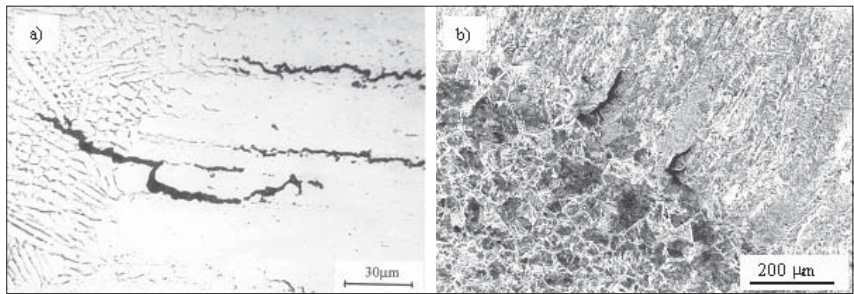

Rys. 12. Pęknięcia segregacyjne w SWC w pobliżu linii wtopienia: a) stal maraging; b) stal St3SJ

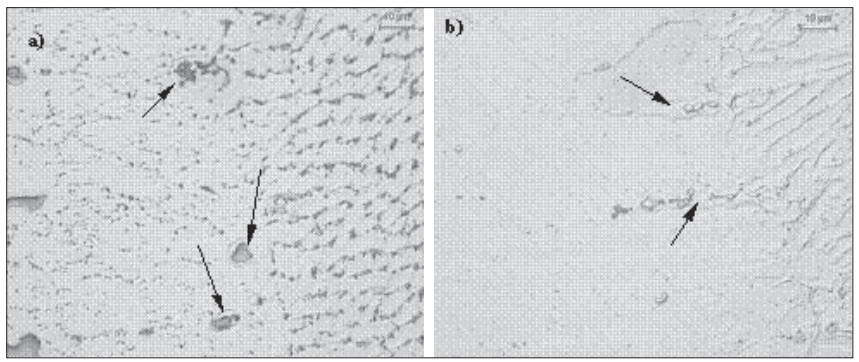

Rys. 13. Równowagowe nadtapianie się węglików tytanu oraz związków międzymetalicznych i wrąceń niemetalicznych w SWC; a - w stali austenitycznej żaroodpornej, b - w stali maraging. Nadtopione obszary wokół cząstek zaznaczono strzałkami

Pierwszy stopień określony jako początek tworzenia się pęknięć jest wywołany obecnością ciekłych warstw na granicach ziaren, na których znajdowały się wtrącenia niemetaliczne np. siarczki, węgliki lub fazy międzymetaliczne (rys. 13). Pojawienie się fazy ciekłej jest

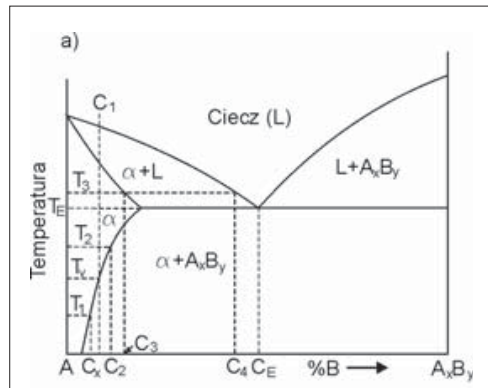

b) wynikiem procesu równowagowego nadtapiania się tych związków a jak wiadomo płynne warstewki cieczy działają osłabiająco, gdyż nie przenoszą odkształcenia plastycznego spowodowanego działaniem naprężeń rozciągających.

Schemat mechani-

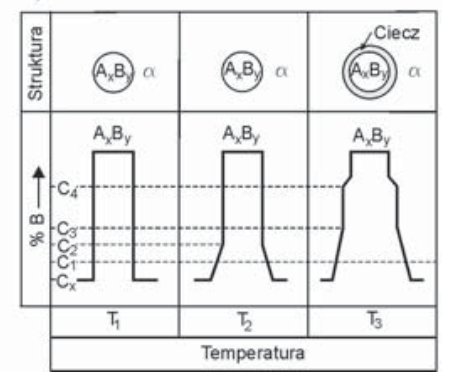

Rys. 14. Równowagowe nadtapianie się związku międzymetalicznego $A_{x} B_{y}$ w SWC: a) - układ podwójny stopu, b) - stopniowe rozpuszczanie się $A_{x} B_{y}$ w różnych temperaturach i tworzenie cieczy

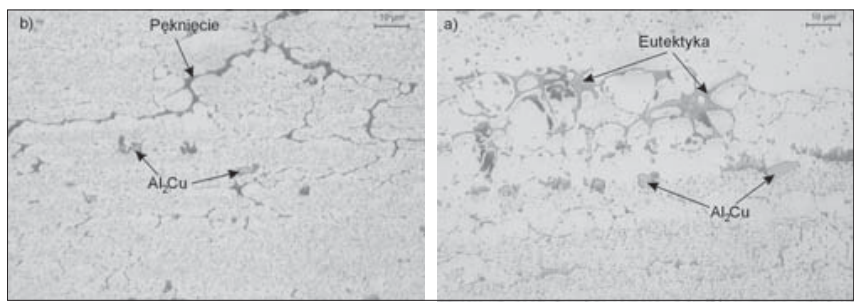

Rys. 15. Mikrostruktura strefy wpływu ciepła w stopie Al-4,5Cu; a) - nadtapianie się fazy $\mathrm{Al}_{2} \mathrm{Cu}$ i przy krzepnięciu powstawanie eutektyki $\left(\alpha+\mathrm{Al}_{2} \mathrm{Cu}\right)$, b) - powstawanie pęknięć w obszarach występowania cienkiej błonki eutektyki bardzo powoli powyżej temperatury solvus $T_{v}$, związek $A_{x} B_{y}$ rozpuszcza się całkowicie fazie $\alpha$ i powstaje jednorodny roztwór fazy a 0 stężeniu $C_{1}$. Kiedy stop $C_{1}$ podczas spawania jest poddany szybkiemu nagrzewaniu do temperatury powyżej $T_{V}$, np. $T_{2}$ związek $A_{x} B_{y}$ zaczyna się rozpuszczać i faza $\alpha$ w kontakcie ze związkiem $A_{x} B_{y}$ osiąga skład $C_{2}$. Związek nie zdąży się jednak rozpuścić i może istnieć $w$ temperaturze wyższej niż $T_{E}$. Zatem $w$ temperaturze $T_{E}$ wspótistnieją faza $\alpha$ oraz pozostałości związku $A_{x} B_{y}$. W wyniku reakcji $A_{x} B_{y} z$ otaczającą fazą $\alpha$ (rozpuszczanie związku $A_{x} B_{y}$ w osnowie $\alpha$ ) w strefie wpływu ciepła na powierzchni rozdziału faza $\alpha-$ związek $A_{x} B_{y}$ tworzy się ciekła eutektyka o składzie $C_{E}$. Przy nagrzewaniu powyżej $T_{E}$ zachodzi $w$ dalszym ciągu rozpuszczanie się $A x B y$ w osnowie i tworzenie większej ilości fazy ciekłej. W temperaturze $\mathrm{T}_{3}$ będą zatem wspótistniały faza $\alpha 0$ składzie $\mathrm{C}_{3}$ i faza ciekła o składzie $\mathrm{C}_{4}$. Przykładem tworzenia się w SWC fazy ciekłej poniżej temperatury solidus, czyli w pewnej odległości od linii wtopienia może być nadtapianie się fazy $\mathrm{Al}_{2} \mathrm{Cu}$ w stopie $\mathrm{Al}-\mathrm{Cu}$ (rys. 15), $\mathrm{Al}_{2} \mathrm{CuMg}$ w stopie Al-Cu-Mg (stopy serii 2000), $\mathrm{Mg}_{2} \mathrm{Si}$ w stopie Al-Mg-Si (seria 6000 ), $Z n_{2} M g$ w stopie Al-Zn-Mg (seria 7000), siarczków tytanu w stali maraging zawierającej $18 \% \mathrm{Ni}$, $\mathrm{NbC}$ lub fazy $\mathrm{Ni}_{2} \mathrm{Nb}$ w stopie Inconel 718 i 625, węglików w super stopach na osnowie Ni, w stalach nierdzewnych itp. Mikrostruktura na rysunku 13 przedstawia przykład tworzenia się poniżej temperatury solidus, cieczy wokół cząstek wydzieleń w SWC stali austenitycznej żaroodpornej i stali maraging. Jeśli faza ciekła występuje na granicach ziaren i ma mały kąt zwilżania z osnową, następuje jej rozpływanie po granicach ziaren. Sprzyjają temu naprężenia, jakie występują w SWC. Rozpływanie się ciekłych faz po granicach ziaren jest szczególnie wyraźne w stali maraging czy stopach na osnowie niklu. Powstałe pęknięcia w wyniku skurczu rozwijają się w kierunku spoiny (rys. 16, 17).
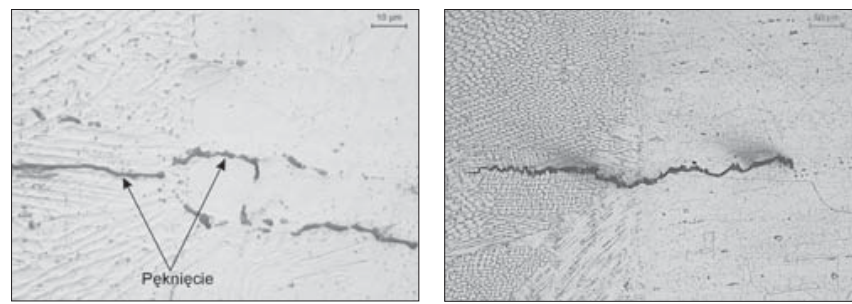

Rys. 16. Powstawanie ciekłej fazy Rys. 17. Pękanie stali austenityczne w pasmach segregacji związków mię- w paśmie segregacji w SWC i rozwijadzymetalicznych w wyniku równowa- nie się pęknięcia do spoiny gowego (kontaktowego) nadtapiania oraz tworzenie mikropęknięć w czasie krzepnięcia i skurczu. Stal maraging

Mechanizm tworzenia pęknięć segregacyjnych na przykładzie nadtapiania siarczków przedstawiono schematycznie na rysunku 18.
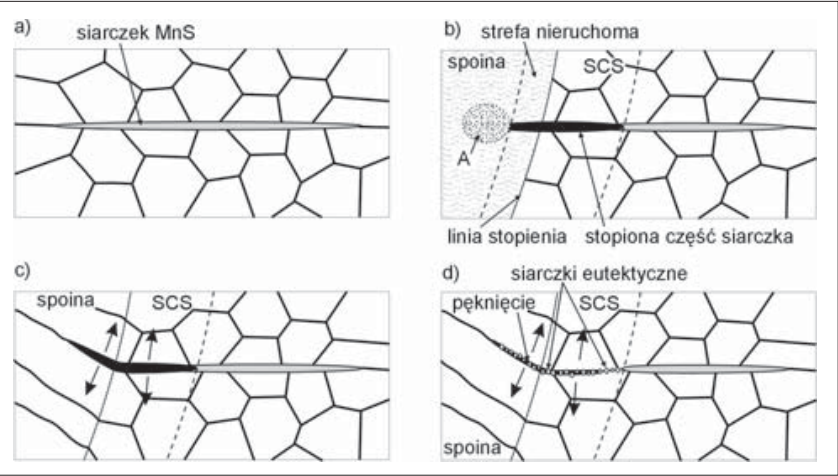

Rys. 18. Mechanizm tworzenia się pęknięć segregacyjnych w wyniku równowagowego nadtapiania siarczków w strefie częściowego stopienia (SCS): a - siarczek MnS przed spawaniem, b - rów-nowagowe nadtapianie się siarczków w strefie częściowego stopienia, c - krzepnięcie spoiny z pozostawieniem na granicach krystalitów cieczy bogatej w domieszkę, $\mathrm{d}$ - tworzenie pęknięć w wyniku działania naprężeń skurczowych i krystalizacja siarczków w postaci eutektycznej, A - obszar ujednorodnienia siarki 


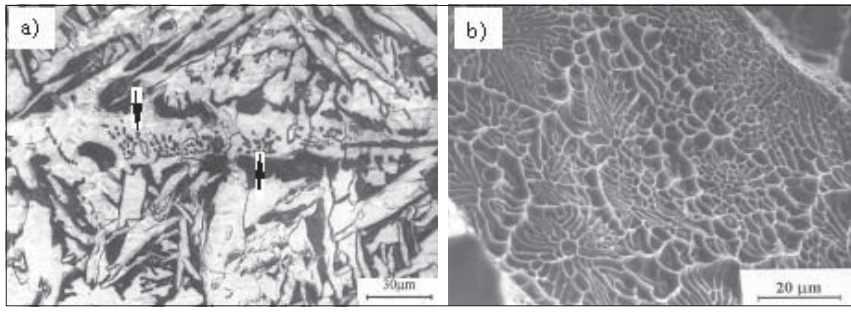

Rys. 19. Nadtapianie się siarczków manganu w stali 18G2A w wyniku działania cyklu cieplnego spawania i powtórna ich krystalizacja w formie eutektycznej: a wygląd eutektyk na zgladzie (zaznaczono strzałkami); b eutektyki siarczkowe na linii wtopienia

Siarczki, które znalazły się w SWC ulegają w wyniku równowagowego nadtopienia stopieniu z utworzeniem warstewki cieczy (rys. 18b). Część cieczy bogatej w siarkę jest usytuowana na granicach ziaren w strefie częściowego stopienia, natomiast część cieczy znajdzie się $w$ spoinie. Przy linii stopienia ciecz bogata w siarkę nie zostaje wymieszana z metalem spoiny z uwagi na istnienie w pobliżu linii stopienia warstwy nieruchomej (tzw. warstwy Nernsta). W czasie chłodzenia krystalizują najpierw obszary 0 wyższej temperaturze krzepnięcia (uboższe $\mathrm{w}$ domieszkę), a więc sąsiadujące z cieczą bogatą w siarkę (rys. 18c). Ciecz zostaje więc zamknięta na granicach ziaren. Już sam proces krzepnięcia zamkniętych objetości cieczy może spowodować powstanie porów skurczowych i nieciaggłości. Jednakże w obszarach, w których występują załamania linii wtopienia $z$ uwagi na zwiększone odksztatcenia, granice ziaren pokryte warstewką cieczy nie mogą przenieść odkształceń i następuje pękanie (rys. 18d). Powierzchnie pęknięć i sąsiadujące z nimi granice ziaren są więc pokryte eutektykami siarczkowymi. Przykład nadtapiania się siarczków manganu i tworzenia eutektyk na granicach ziaren potwierdzający przedstawiony mechanizm pękania pokazano na rysunku 19. Powstałe w wysokich temperaturach pęknięcia w czasie chłodzenia mogą dalej rozprzestrzeniać się. W początkowym okresie pęknięcia mają przebieg międzykrystaliczny. Dalsze chłodzenie i przemiany fazowe mogą powiększyć mikropęknięcia do wielkości makropęknięć. Rozwój pęknięć może przyspieszyć dyfundujący wodór.

Stwierdzono, że wrażliwość stopu do pęknięć krystalizacyjnych zależy od zakresu temperatur krystalizacji oraz od ilości i rozmieszczenia cieczy bogatej $w$ domieszkę. Większy zakres temperatur krzepnięcia zwiększa rozmiar obszaru stało ciekłego wrażliwego na pękanie, które zarówno ciągnie się za jeziorkiem spawalniczym jak i występuje w strefie częściowego stopienia. Stopy niklu typu Inconel 625 podlegają trzystopniowej krystalizacji [2, 3]. Najpierw w temperaturze likwidus $1368^{\circ} \mathrm{C}$ z cieczy $L$ wydziela się austenit $(L \rightarrow \gamma)$, potem $\mathrm{w}$ temperaturze $0 \mathrm{k} \cdot 1350^{\circ} \mathrm{C}$ rozpoczyna się wydzielanie eutektyki węglikowej $\mathrm{L} \rightarrow \gamma(\gamma+\mathrm{NbC})$, a w temperaturze $1152^{\circ} \mathrm{C}$ krystalizacja kończy się utworzeniem eutektyki $\mathrm{L} \rightarrow \gamma\left(\gamma+\right.$ faza Lavesa $\left.\mathrm{Ni}_{2} \mathrm{Nb}\right)$. Tak więc zakres temperatur krzepnięcia wynosi ponad $200^{\circ} \mathrm{C}$. Tak szeroki zakres krzepnięcia sprzyja powstawaniu pęknięć gorących w spoinie.

Reakcje te mają również istotne znaczenie $w$ procesie inicjowania pęknięć w strefie wpływu ciepła w wyniku równowagowego nadtapiania. Mechanizm pękania na gorąco w SWC stopów inconel przedstawiono schematycznie na rysunku 20 . W strefie wpływu

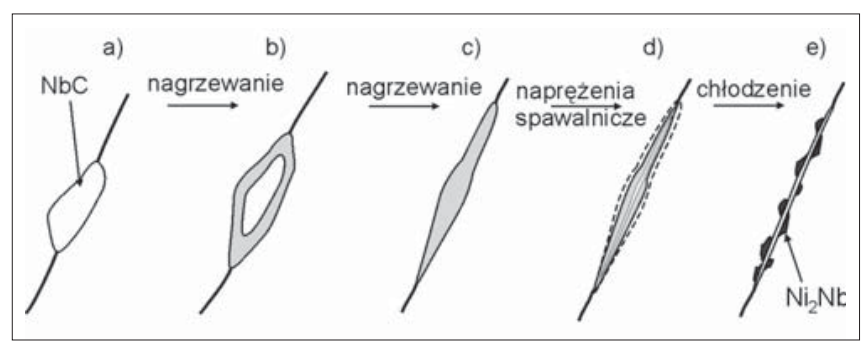

Rys. 20. Mechanizm tworzenia się mikropęknięć w strefie wpływu ciepła w wyniku równowagowego nadtapiania się węglików NbC i ponownej krystalizacji cieczy w formie eutektyki $\left(\gamma+\right.$ faza Lavesa $\left.\mathrm{Ni}_{2} \mathrm{Nb}\right)$ ciepła w temperaturze powyżej $1350^{\circ} \mathrm{C}$, a poniżej temperatury solidus następuje nadtapianie się węglików niobu z utworzeniem cieczy. Ponieważ węgliki znajdują się głównie na granicach ziaren, powstała ciecz dobrze zwilża granice i pod wpływem naprężen rozpływa się po nich. Podczas chłodzenia ciecz zostaje szybko ochłodzona poniżej temperatury wydzielania eutektyki $\gamma+$ faza Lavesa $\mathrm{Ni}_{2} \mathrm{Nb}$. Krzepnięcie eutektyki i związany z tym skurcz może powodować pojawienie się pęknięć po granicach ziaren. Przykład rozpuszczania się w SWC węglika NbC i tworzenie wokół niego fazy Lavesa Ni2Nb przedstawiono na rysunku 21.

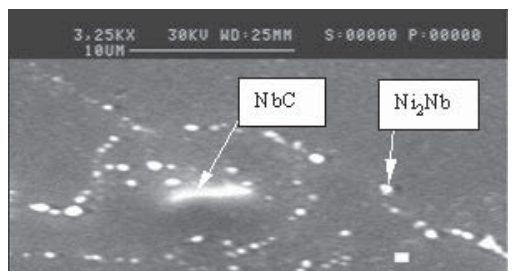

Rys. 21. Równowagowe nadtapianie się węglików $\mathrm{NbC}$ w SWC i ponowna krystalizacja cieczy w formie eutektyki $\left(\gamma+\right.$ faza Lavesa $\left.\mathrm{Ni}_{2} \mathrm{Nb}\right)$

\section{Podsumowanie}

Przedstawione w artykule mechanizmy powstawania pęknięć są podstawą do weryfikacji metod, parametrów spawania oraz doboru materiałów spawalniczych. Odpowiedni dobór tych czynników pozwoli na obniżenie skłonności do powstawania pęknięć. Projektując węzly spawalnicze należy zwracać uwage na zminimalizowanie sztywności połączenia w procesie spawania. Istotne znaczenie ma również szybkość narastania odkształceń w czasie krzepnięcia Badania Yanga [4] wskazują, że istnieje możliwość ograniczenia skłonności do pękania poprzez wzrost szybkości krzepnięcia. W stopie aluminium 2024 spawanym metodą GTAW, uniknięto pęknięć kierując strumień ciekłego azotu na spoinę (poza jeziorkiem), co zwiększyło szybkość chłodzenia i krzepnięcia.

Podczas spawania długich sekcji blach np. w stoczniach, peknięć gorących można uniknąć przez odpowiedni dobór elastycznej płyty wybiegowej [5] która zmniejsza gwaltowną zmianę sztywności przy przejściu łuku z blachy spawanej na płytę wybiegową.

Odpowiedni dobór materiałów spawalniczych, właściwy stopień wymieszania stopiwa z materiałem spawanym oraz kontrolowany (wypukły) ksztatt lica jest podstawą do uzyskania spoin bez pęknięć w stalach austenitycznych i w stopach niklu.

Podstawową przyczyną pekania gorącego w SWC jest obecność segregacji wtrąceń niemetalicznych. Proces równowagowego nadtapiania powoduje, że nawet w dalszej odległości od linii wtopienia może pojawić się niewielka ilość fazy ciekłej, która przy współdziałaniu z naprężeniami skurczowymi prowadzi do powstania mikropęknięć po granicach ziaren.

W stopach na bazie niklu procesowi pekania sprzyja szybkie chłodzenie i możliwość tworzenie się niskotopliwej eutektyki ( $g$ faza Lavesa $\left.\mathrm{Ni}_{2} \mathrm{Nb}\right)$ o temperaturze krzepnięcia $1152^{\circ} \mathrm{C}$. Obecność węgla i zmniejszenie szybkości chtodzenia prowadzi do powstania eutektyki $(\mathrm{g}+\mathrm{NbC})$, której krzepnięcie rozpoczyna się w temperaturze $1350^{\circ} \mathrm{C}$. Zmniejsza się więc zakres temperatur krzepnięcia co znacznie podnosi odporność do pękania na gorąco.

W stopach Al-Cu podstawowa przyczyna pekania w SWC jest obecność dużych cząstek związków międzymetalicznych Al2Cu lub związków międzymetalicznych aluminium z żelazem, które w wyniku równowagowego nadtapiania, tworzą w SWC lokalne skupiska cieczy. Duży skurcz aluminium w procesie chłodzenia prowadzi do rozpływania się cieczy po granicach ziaren w postaci cienkiej błonki, co jest bezpośrednią przyczyną pękania.

\section{Literatura}

[1] Schabereiter H i inni: Możliwości unikania wad spowodowanych czynnikami metalurgicznymi przy spawaniu stali nierdzewnych, Materiały Seminarium Instytutu Spawalnictwa nt. „Spawanie nowoczesnych gatunków stali", Czerwiec 1995.

[2] Dupont J. N., Banovic S. W., Marder A. R.: Evolution and Weldability of Dissimilar Welds between a Super Austenitic Stainless Steel and Nickel-Based Alloys Weld. J. 82,2003.

[3] Kou S.: Welding Metallurgy Wyd. Wiley Interscience, wyd. 2. 2003

[4] Yang Y. P., Dong P., Zhang J., Tian X.: Weld. J. 79, 2000.

[5] Pchennikov A., Streitenberger M., Herold H.: Ksztattowanie i montaż dla jednostronnego spawania dużych elementów bez pęknięć krystalizacyjnych, Biuletyn Instytutu Spawalnictwa nr 6/2003 